\title{
In de beperking toont zich de meester - gezondheidsrecht tussen geneeskunde en recht
}

Citation for published version (APA):

Roscam Abbing, H. D. C. (1983). In de beperking toont zich de meester - gezondheidsrecht tussen geneeskunde en recht. Samsom. https://doi.org/10.26481/spe.19831007hra

Document status and date:

Published: 07/10/1983

DOI:

10.26481/spe.19831007hra

Document Version:

Publisher's PDF, also known as Version of record

\section{Please check the document version of this publication:}

- A submitted manuscript is the version of the article upon submission and before peer-review. There can be important differences between the submitted version and the official published version of record.

People interested in the research are advised to contact the author for the final version of the publication, or visit the DOI to the publisher's website.

- The final author version and the galley proof are versions of the publication after peer review.

- The final published version features the final layout of the paper including the volume, issue and page numbers.

Link to publication

\footnotetext{
General rights rights.

- You may freely distribute the URL identifying the publication in the public portal. please follow below link for the End User Agreement:

www.umlib.nl/taverne-license

Take down policy

If you believe that this document breaches copyright please contact us at:

repository@maastrichtuniversity.nl

providing details and we will investigate your claim.
}

Copyright and moral rights for the publications made accessible in the public portal are retained by the authors and/or other copyright owners and it is a condition of accessing publications that users recognise and abide by the legal requirements associated with these

- Users may download and print one copy of any publication from the public portal for the purpose of private study or research.

- You may not further distribute the material or use it for any profit-making activity or commercial gain

If the publication is distributed under the terms of Article $25 \mathrm{fa}$ of the Dutch Copyright Act, indicated by the "Taverne" license above, 
In de beperking toont zich de meester 


$$
\text { • }
$$




\title{
IN DE BEPERKING TOONT ZICH DE MEESTER
}

\author{
Gezondheidsrecht \\ tussen geneeskunde en recht
}

\section{Rede}

uitgesproken bij de aanvaarding van het ambt van buitengewoon hoogleraar in het gezondheidsrecht aan de Rijksuniversiteit Limburg op vrijdag 7 oktober 1983

door

mr. dr. H.D.C. Roscam Abbing 
ISBN 901403357

Copyright (C) H.D.C. Roscam Abbing, Amsterdam

Behoudens de in of krachtens de Auteurswet 1912 gestelde uitzonderingen mag niets uit deze uitgave worden vervectwoudigd en/of openbaar gemalat door middel wan druk, fotokopie, microfilm, of op welke andere wijze dan ook zonder de voorafgaande schriftelijke toestemming wan Samsom Uitgewerij b. w. gevestigd te Alphen aan den Rijn, die daartoe door de auteurs rechthebbende met uitshituing van ieder ander is gerechtigd. 
Justitia est constans et perpetua volunas ius sum cuique tribuere (Ulpianus)

Heath is a state of complete physical, mentah and social well-being and not merely the absente of disease or infirmity

(World Health Organization) 



\section{Inleiding}

Begin dit jaar, op 17 februari 1983, is de gewijzigde grondwet in werking getreden. De klassieke grondrechten hebben uitbreiding ondergaan, onder andere met het recht op bescherming van de persoonlijke levenssfeer en het recht op hichamelijke integriteit (artikelen 10 en 11)*. Beide reclaten spelen een belangrijke rol in de gezond heidszorg en, een onderdeel daarvan, de geneeskunde. Het reeds gerume tijd door juristen (waaronder met name Leenen') als een van de belangrijkste uitgangspunten in de gezondheidszorg gehanteerde beginsel dat de mens zelf beslist over datgene wat gebeurt met zijn lichaam of geest en dat derhalve alleen hij, en niet zijn arts, beslist over het al dan niet ondergaan van een medische behandeling of ingreep, is hiermede als een - owerigens reeds geruime tijd door de Nederlandse regering in internationaal verband erkend - grondwettelijk recht in ons staatsbestel vastgelegd.

Nauw in relatie tot het zelfbeschikkingsrecht in de gezondheidszorg staat het eveneens bij de recente grondwetswijziging in ons staatsdocument van de hoogste orde verankerde recht op gezondheidszorg (artikel 22)**, een sociaal grondrecht, dat evenzeer door de Nederlandse regering eerder in internationaal verband werd onderschreven.

\section{Grenzen gezondheidszorg}

De gezondheidszorg ontleent zijn legitimatie aan beide soorten van rechten en vindt in beide zijn begrenzing. De grenzen aan het recht op gezondheidszorg worden gesteld door zowel. de medische en technische alsook door de financieel-economische mogelijkheden.

* Arrikel 10

1. Teder heef, behoudens bij of krachtens do wet te stellen beperkingen, rech op cerbic diging van zijn persoonlijke lewenssfeer.

2. De wef stelit regels ter bescherming van de persoonlijke levenssfeer in verthund me het vastleggen en verstrekken wan persoonsgegevens.

3. De wet steli regells inzake de aanspraken wan personen op kennismeming van ower hen vastgelegde gegevens en van het gebruk dat datarvan wordi gemake, alsmede op verbetering wan zodanige gegevens.

Artikel ill

leder heef, behoudens bij of krachtens de wet stellen beperkingen, recht opin orianutast* baarheid vara zijn lichaam.

"* Artikel 22

1. De overthed treft matregelen ter bevordering van de volksgezondheid. 
Ten aanzien van grenzen wan de gezondheidszorg kan een onderscheid worden gemaak: wusgen extern bepaalde en intern bepaalde grenzen. Onder interne grenzen worden in dit verband verstaan grenzen, die aff te leiden zijn uit de aard en het doel van de gezondheidszorg zelr. Bij exteme grenzen zijn wagen aan de orde met betrekking tot externe besituring, van butter af werkende factoren e.d. ${ }^{2}$ Beide aspecten van begrenzing van het recht op gezondheidszorg zullen aan de orde komen, waarbij de aandach met name gericht zal zijn op één van de belangrijkste onderdelen van de gezondheidszorg, de geneeskunde.

De mate waarin en de wijze waarop de overheid in het kader van onze huidige samenleving de gezondheidszorg bevordert hangt af van de beschikbare middelen en de door regering en parlement binnen de bestaande ruimte te stellen prioriteiten. Deze externe bepaling van de grenzen van de gezondheidszorg in ruime zin, bepaalt tevens de ruimte voor het bandelen van artsen en juristen in de gezondheidszorg, uiteraard vanuit de benaderingswijze welke specifiek is woor de respectiewelijke vakgebieden. De medische professie stellt de medische wetenschap en zorgverlening ten dienste van de mens en draagt in die zin bij aan de realisering van het recht op gezondheidszorg. Het medisch handelen is hierbij niet beperkt tot de enkele arts-patiënt relatie (het zgn. medisch model, $c f$. de leer van Aesculapius) maar omvat tevens de sociale dimensie (het zgn. sociale model, cf. de leer van Hygeia). De juridische professie draagt bij tot realisering van het recht op gezondheidszorg door onder meer het formuleren van juridische randwoorwaarden ten aanzien van het zorgverleningssysteem en het formuleren van regels ten behoeve van gebruikers van gezondheidszorgvoorzieningen en wan hulpverleners in de gezondheidszorg.

De arts is bij zijn medisch handelen enerzijds gebonden aan de medisch-professionele standaard, anderzijds aan het zelfbeschikkingsrecht van de mens tot uitdrukking komend (in normale omstandigheden) in de wilsverklaring van de patiënt. In de individuele arts-patient relatie betekent dit laatste dat de arts daar terugtreeclt waar de patiënt dit verlangt.

Artsen oefenen hun beroep uit bij de gratie van het recht op zelfbeschikking, als hoeder waarvan onder andere de jurist optreedt. Gezonctheidsjuristen oefenen hun vak uit bij de gratie van de geneeskunde, als hoeder waarvan de arts optreedt.

Beiden, art en jurist, spelen een nauw verweven rol in het nastreven van de verwezerilijking wan het recht op gezondheidszorg en het zelfbeschikkingsrecht van de mens. Zoals reeds is iangegeven verwullen beiden een belangrijke maatschappelijke functie ten opzichte vam de gezondheid van de mens en hebben beiden een belangrijke taak en functie ten atanzien van de rechten en plichten van de patiënt.

Voor beiden geldt dat zij niet eenzijdig kunnen functioneren in de gezondheidszorg. Voor beiden geldt het spreekwoord 'In de beperking toont zich de meester". 


\section{Beperkingen handelen arts}

Hoewel het streven in de geneeskunst als zodanig onbegrensd is, worden de mogelijkheden van geneeskundig handelen beperkt door de grenzen van het medisch kun. nen. ${ }^{3}$ Dit medisch kunnen ontwikkelt en perfectioneert zich nog steeds. Nog andere grenzen worden aan de geneeskunde gesteld. Grenzen, zoals gezegd, door de beperking van het recht op gezondheidszorg en het zelfbeschikkingsrecht van de mens. Aan de andere kant mag de arts zün grenzen niet te nauw trekken. Hij zal zich in zijn handelen niet enkel kunnen laten leiden door het zgn. medisch model; hij kan ds mens nier enkel benaderen vanuit een biomedische, objectiverende inwalshoek." De mens is niet enkel object van medisch handelen, maar dient tevens als persoon te worden benaderd, als drager van normen en warden. Grenzen worden dus niet alleen gelegd door de medische mogelijkheden, maar ook door de maatschappetijke factoren, de ethische opvattingen met betrekking tot medisch handelen en aor de individuele wilsbepaling van de mens. Indien de arts enkel zou handelen conform de medische regels, dat wil zeggen conform de medische wetenschap en erwaring; dan zou hij zijn macht stellen tegenover de onmacht van de patiënt.

\section{Beperkingen handelen jurist}

Er bestaan evenzeer grenzen aan het handelen van de jurist. Zo dient de jurist er voor te waken terecht te komen in de valkuil, welke dreigt indien wordt toegegeven aan de neiging het recht te hanteren als een enkel juridisch instrumentarium. Hij hanteert het recht dan niet meer zozeer ter oplossing van problemen, maar gebruikt veeleer het juridisch instrumentarium ter verkrijging van volmaakte rechtszeker" heid. ${ }^{5}$ Van een overmaat van regelgeving en procedures kan een verlammende werking uitgaan: in plaats van een synthese ontstat een antithese. Het formuleren wan wetten, het stellen van regels en het ontwerpen van procedures mag geen doel op zich zijn. Het juridisch instrumentarium dient enkel gehanteerd te worden, indien er geen andere geëigende middelen zijn het beoogde doel te bereiken. Hierbij zal de jurise tevens oog dienen te hebben yoor de wisselwerking tussen en de wederaijdse beinwloeding van diverse lacetten van de gezondheidszorg. Zo maken de platats dis de gezondheidszorg innemt in de samenleving, de organisatie van de gezondheidszorg alls systeem en van de hulpverlening in de gezondheidszorg, de positie van de individu daarbinnen en de ontwikkelingen in de greneeskunde, het gezondheidszorgstelsel tot een uiterst gevarieerd complex geheel, dat de jurist in zijn overwegingen moet betrekken. De jurist die, zonder acht te slatan op de veelheid van relaties in en de mate van verwevenheid van de diverse onderdelen van de gezondheidszorg op micro", meso-en macroniveau, zowel horizontaal als vertikaal, bepaalde vraagstukken in de gezondheidszorg eenzijdig benadert en benadrukt, kent zijn beperkingen niet. 
De jurist heffn tot taak vanüt een everwichige, samenfangende benachering te ordenen, om conllicten te voorkomen en soms conflicten juridisch op te lossen. De jurist formulect darbij regels en procedures op grond van matschappelijke verhoudingen en ontwikkelingen, warbij onevenwichtige situaties in exerwicht worden gebracht. Een dergelijke onewenwichtigheid in regelgeving is bijwoorbeeld historisch gegrotid ten anzien wan de medische beroepseofenaars, onder andere vanuit de wers wan de medische professie zijn positie door regelgeving te verstevigen."

De jurist zal dan ook een adequat antword dienen te geven op de de laatste tijd steeds meer geuite en zeer wel verklaarbare wens van de consument tot regelgeving van ëjn rechtspositie om meer evenwicht te bereiken. Hier dient de jurisit er echter op bedacht te zijn dat aan een te ver doorgevoerde regelgeving ten behoeve van de consument ook nadelige aspecten voor de patient verbonden kunnen zijn. De arts kan zich dan immers genoodzaakt voelen, als reactie hierop, zich te verweren en aan te drungen op nieuwe regelingen ter bescherming van het eigen medisch handelen of zells het feiler uit te suiten, war dit menseligherwijs niet wit te sluiten walt. * Overacentuering van de positie wan de tene partij in de verhouding arts-patiën leidt tot verstoring wan de evenwichtssituatic, waarbij moet worden overwogen dat de patiént de zwakste partij is.

Voorop dient te staan dat de jurist miet dient toe te gewen aan de neiging de arts-patient relatie te willen vatten in een veelheid van soms verstarrende en daardoor die relative verstorende regells..

Dit is geen pleidooi voor deregulering in de gezondheidszorg. Het is wel een pleidooi voor weloverwogen regelgeving. Waar wettelijke regels de noodzakelijke rechtsbescherming in de gezondheidszorg moeten bieden, waar in dat opzicht van lacunes sprake is, is regelgeving geboden. ${ }^{9}$ Zo is er bijwoorbeeld een lacune op het terrein wan medische experimenten. Ook bij toekomstige nieuwe ontwikkelingen, zoals ten aanzien van recombinant-DNA, kan een extra bescherming van de rechten wan de mens in de gezondheidszorg nodig worden. ${ }^{10}$

Bestande regelgeving in de gezondheidszorg dient kritisch doorgelicht te worden op doelmatigheid en doeltreffendheid: war mogelijk dient vereenvoudiging van regels en procedures te worden nagestreefd.":

- De geschiedenis van thet ziekenlondsbestel is een goed voorbeeld van de aandrang van de - privaarechtelijke w artsenorganisane te komen tot een liefst zo gedetailleerd mogelijke publickrechtelijke regeligeving ${ }^{6}$

* "Zowel Leencen " als v.d. Minn hebben geweren op de noodzata van terughoudendheid van de wetgever net betrekking tot medisch hardilen. In essentie kom thet er op neer, dat medisch handelen zich slechts marginat leent voor wetgeving. Evermin zal het formuleren wan standaardregels te hanteren bij medisch handelen in concrete gewallen een oplossing kunnen biedery. 


\section{Evenwicht door weloverwogen gebruilk van rechtssprak}

Zowel artsen als patiënten vertonen nog weleens de neiging problemen die er bestaan eerder op te lossen met behulp van juridische instrumenten, dan via andere, meer geëigende wegen. Dit komt onder meer tot uitdrukking in een in mijn ogen onrustbarende toename van juridische procedures.

Een soms niet onbelangrijke vertraging in te behandelen rechtszaken op thet terrein van de gezonddheidszorg is hiervan het gevolg. Het is duidelijk dat hieraan grote nadelen verbonden zijn, zoals het woortbestaan van conflicten en onzekerheid.

Oneigenlijk gebruik van het juridisch instrumentarium kan er zelfs toe leiden dat nieuwe problemen ontsitaan of conflicten verergeren. $Z_{0}$ heeft in de Verenigde Staten zich de voor de hand liggende ontwikkeling van het ontstaan van een schade-actie door hulpverleners voorgedaan, bijvoorbeeld ingeval een patient de hulpverlener ten onrechte heeft aangeklaagd. Ook hier wordt de antithese in de hand gewerkt. Rechtspraak moet ten dienste staan van handhaving en bevordering van rechtsbeginselen als geen andere middelen beschikbaar zijn, Belangrijker is, dat deze rechtsbeginsellen, met name ook door hulpverleners, in hun dagellijks werk worden verwezenlijkt.

\section{Het duo arts-jurist}

Het recht dient er voorts toe de arts in twijfelsituaties of in situaties warbij de plichten dreigen te conflicteren, oplossingen aan te bieden. Zo zal het recht regelen in welke gevallen van gangbare normen mag worden afgeweken, Ook beschermt de ju* rist de arts wel tegen zichzelf: hij reikt normen en criteria aan zodat het handelen van de arts binnen de professionele standaard plaats vindt.

Als bijwoorbeeld de arts enkel acht dreigt te slaan op de medische aspecten, schiet de jurist te hulp door alandacht te vragen voor de rechten van de patiënt en de maatschappelijke functie van de geneeskunde. De jurist dient, om dit te kunnen doen, begrip te hebben woor het handelen en de beslissingen wan de arts. Zonder kennis van de problemen waarmee de arts bij de uitoetening wan zijn functic wordt geconfronteerd, zonder zich bewust te zijn van de onzekere factoren van de geneeskunde kan hij noch de arts, noch de patiënt van dienst zijn. De arts dient omgekeerd begrip te hebben voor de jurist, voor de taak van de jurist evenwichtige verhoudingen na te streven en de realisering van individuele en sociale grondrechten te warborgen.

Erkelens ${ }^{12}$ heeft in zijn begin dit jaar te Utrecht gehouden oratie aangedrongen op een op nadenken en kernis gebaseerde terughoudendheid van de arts ten aanzion van diagnostiek en therapie. Ik wil hier een extra dimensie aan toevoegen. Het past de medicus in zijn relatie tot de patiënt terughoudendheid te betrachten op basis van de rechten van de patiënt, als mens met eigen normen en waarden. 
Het is an de jurist de medicug begrip en inzich bij te brengen omtrent de inhoud wan de juridische aspecten van de gezondheidszorg en van de relatie arts-patient, zodat het handelen van de arts mede grondslag vindt in rechisnormen. Het is evenzeer aan de jurist de patient de mogelijkheden en on mogelikheden wan het recht te laten zilen. Ook de patient behoort het evenwicht tusgen eigen belang, de positie van de arts on wan de gemeenschap in het oog te houden. De patient dient voorts het bestan vain onzekerheden in de geneeskunde the erkennen.

\section{Bevorderingsstaat}

Het handelen wan artsen en juristen in de gezondheidszorg wordt tewens bepaald en beinvloed door de rol die de staat daarbij vervult.

Na de liberale statstsopwatting waarin de grondwettelijke vrijheid van de burger voorop stond is in de 20 eeuw, met name na de tweede wereldoorlog, de "verzorgingsstaat' ontwikkeld. In de 'verzorgingsstat' is sprake van sterk toegenomen overheidsbemoeienis gericht op vergroting van welzijn en van het welvaartsniveau. ${ }^{13}$ Thans bevinden wij ons naar mijn mening in het beginstadium wan wat ik de 'bevorderingsstaat' zou willen noemen, waarin de overheid voor de toepassing van sociale grondrechten " op basis van op democratische wijze, in onderlinge afweging gemaakte keuzen en gestelde prioriteiten, binnem de daaraan van te voren expliciet gestelde grenzen, zorg draagi, zonder de uitvoering siteeds zelf ter hand te nemen.

In de 'bevorderingsstaat' is sprake van vermindering van overheidsbemoeienis, van privatisering van datgene wat de overheid tijdens de "verzorgingsstaat" heeft overgenomen aan eigen verantwoordelijkheid en aan mogelijkheid tot zelfregullering. De tijdens de 'verzorgingsstaat' toegenomen overheidsregulering en -toezicht worden dan werminderd ten gunste van bevordering van de zelfstandigheid, zowel in de individuele relaties als op institutioneel niveau.

In de 'beworderingsstaat' zal de overheid zich meer beperken tot het scheppen van randwoorwaarden, tot het optreden in de voorwaardenscheppende sfeer ten aanzien van het verwezenlijken van sociale grondrechten. De afhankelijkheid van overheidsoptreden als (uitwoerend) regelgever, welke de verzorgingsstant met zich heeft gebracht, zall worden omgezet in een zekere verzelfstandiging van de samenleving. In de gezondheidszorg zal de verantwoordelijkheid van de overheid in het kader van de grondwettelijke takk de volksgezondheid te bevorderen, welke in de loop der tijd is vertaald in een de gezondheidszorg beheersende, zo niet overheersende beinvloeding, tot uitrukking komen in het scheppen wan een dusdanig (wetteljk) kader, dat daarbinnen rumte is voor zelfordening, zelfwerkzaamheid en eigen verantwoordelijkheid. Op dez wijze zal het evenwicht tussen het ene uiterste, van het 'laissezfaire, laissez-aller' beginsel van de liberale rechtsstaat, en het andere uiterste, het ovememen door de overheid van eigen venantwoordelijkheid van de individu in het kadet van de "verzorgingstart", tot stand worden gebracht. Dat deze overgang van 
"verzorgingsstaat" naar "bevorderingsstaat" in gang is gezet, moge ondwe andere blij" ken uit het streven naar deregulering en privatisering, ook in de gezondheidszorg, alsmede uit de accenverlegging in de gezondheidszorg van grotendeels institutionele zorg-en hulpverlening naar onderlinge hulp- en dienstverlening. Ook het democratiseringsproces in de gezondheidszorg is hier een voorbeeld van. De overheid bliff verantwoondelikheid dragen voor een kwallitatief verantwoorde, geografisch bereikbare en financieel toegankelijke gezondheidszorg binnen de daarann extern te stellen grenzen. De overheid zal zich hierbij, voorzover de verhoudinger in de gezondheids. zorg dit toelaten, beperken tot een stimulerende, bevorderende rol. Het veld van de gezondheidszorg zal hier op een adequate wijze op dienen in te spelen, wil deze uit een oogpunt van zellbeschikkingsrecht van de mens gunstige ontwiklkeling kunnen doorzetten. Het leggen van een groter accent op de onderlinge relaties en de eigen verantwoordelijkheid vereist tegelijkertijd meer zelfdiscipline en meer zelfbeperking zowel van de hulpverleners, als van de patient.

Wil de gezondheidszorg in een dergelijke staatsopvatting blijven functioneren op ba* sis van algemene beginselen van rechtvaardigheid, rechtsgelijkheid en rechtsbescherming, waarbij algemeen juridische, ethische normen en matstaven in acht worden genomen, dan is het meer dan ooit noodzakelijk dat de medische en juridische professie in goede onderlinge harmonie en samenwerking streven naar instandhouding en bevordering wan de evenwichtssituatie in de gezondheidszorg. De druk waaronder het handhaven wan die evenwichtssituatie kan komen te staan, zal nog worden vergroot doordat tegelijk met het bereiken wan de grenzen van de verzorgingsstaat de grenswerlegging in de medische wetenschap doorgat.

Die toename van mogelijkheden in de geneeskunde zal nieuwe vragen wan onder meer juridische aard oproepen. Dit zal vragen om herbezinning over normen en waarden, om herwaardering van beginselen van rechtsbescherming en rechtvaardige verdeling en dit niet alleen woor ons geslacht, maar ook voor toekomstige generaties . Dat bij een groei van medische mogelijkheden gelijktijdig sprake zal zijn van af name van financiële ruimte, zal de behoefte aan nieuwe rechtsnormen doen toenemen.

\section{Keuzen}

Het beginsel wan rechrvardige verdeling dat hierbij centraal staat, brengt met zich dat de medische professie niet alleen kan beslissen hoe bijyoorbeeld de rieuwe behandelingsvormen ontwikkeld en verdeeld zullen worden. Niet uitslutend do wens tot verbetering van de reeds bestaande medische zorg of de wens tot vergroting van de medische-technologische mogelijkheden en de toepassing daaruan zijn daarbij maatgevend. Andere factoren zullen bij de noor een niet onbelangrijk deel door an. deren te maken keuzen moeten worden overwogen, zoals het algemeen levensniveau, de kosten versus de baten, de mate warin de ziekte voorkomt, de mate waarin mensen profigt kunnen hebben van de nieuwe ontwikkelingen (zowel kwalitatief als 
kwantitatief), de vraag naar wat fundamentele behoeften zijn in de gezondheidszorg. wat nog aan waarde kan worden toegevoegd aan reeds bestaande mogelijkheden (rocgevoegde meewwarde) e d it Ook dienen eenmaal gemaakte keuzen regelmatig geêvalueerd te worden; gestelde prioriteiten dienen regelmatig te worden getoetst. Naast deze vraagstukken van proriteiten op macro-niveau waarbij de jurist een bijdrage kan leveren door het aanreiken van op macro-niveau te hanteren normen en criteria, kom het selectievraagstuk op micro-niveau meer en meer aan de orde. Ook hier zall de jurist de samenleving, de patiënt en de arts bijstaan om te komen tot een zo rechtwaardig mogelijke werdeling door het ontwikkelen van normen en procedures."

Tegelijk met de toename wan de potentiele woordelen van vernieuwing in de geneeskunde zullen ook de potertiële risico's toenemen. Hierdoor dreigt de evenwichtige verhouding tussen enerzijds de groei van de technische mogelijkheden in de gezondheidszorg en anderzijds de daardoor aan die gezondheidszorg toegevoegde waarde verstoord te raken. De huidigen tendens te komen tot - veelal kleine - subspeciallsaties houdt ook de nodige risico's in, zowel voor de arts, die hierdoor te eng georiënteerd kan raken, als woor cle patiënt, die kan worden blootgesteld aan een in verhouding te veel aan onderzoekingen. V.d. Meer ${ }^{16}$ merkte begin dit jaar op, dat naarmate het diagnostisch proces verder voortschrijdt, de kosten in tijd en geld stijgen zonder dat allijd duidelijk is wat de baten voor de patiënt zijn. Leenen ${ }^{17}$ heeft er op gewezen dat meer medische behandelingen niet zonder meer in het belang van de patiënt zijn.

Van Es ${ }^{16}$ vroeg aandacht voor de vicieuze cirkel waarin we dreigen terecht te komen doordat veel wan de door de geneeskunde opgeloste problemen nieuwe problemen zullen creëren, die het gevolg zijn van op genezing gerichte hulpverlening. * * Aan de andere kant kunnen nieuwe ziekten optreden, waar ons resistentiesysteem niet meer op is ingesteld, en waar de medische wetenschap nog geen antwoord op heeft. Denk bijvoorbeeld aan het Acquired Immune Deficiency Syndrome (AID). Ook kan het leven van pasgeborenen nadelig beïnvoed zijn door verschillende factoren, waaronder iatrogene, zo zelfs, dat de medische professie zich geplaatst kan zien voor de keuze tussen instandhouding van nieuw leven door medisch gezien zinloze behandeling en beslissing tot niet behandelen.

- De Vereniging voor Gesondheidstecht heef in een studie naar selectiecriteria op micro-nveat een aranzet gegeven woor de ontwikkeling van theorievorming op dit terrein. ${ }^{15}$

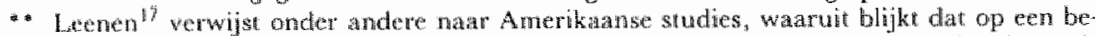
paadd punt niewwe medische handelingen niet meer toevoegen aan de gezondheid van de patiant. Alsdan doorgan met diagnostische en therapeutische handelingen kan schadelijk xijn woor de pationt en zells leiden tot het on staan van iatrogene zickter. Zo ook Van Es, die en wanverhouding constateen tussen bet kunmen warn de medische wetenschap en het tekort schietern van de werkelijke hulpverlening. 


\section{Kwetsbaarheid van de patiènt}

De patiënt is door de verbreding en intensivering van onderzoeks-en behandelingsmogelijkheden kwetsbaarder geworden en voelt zich tegelijk bedreigd door nicuwe ziekten. Dergelijke ontwikkelingen zullen de individuele arts-patiënt relatie beinvloeden. Hel wordt dan van des te groter belang het handelen van de arts te toetsen aan normen en regels, die door het recht moeten worden aangedragen. Deze toetsing tast niet, zoals weleens uit de medische professie naar voren wordt gebracht, de professionele autonomie van de arts aan en beperkt evenmin op onrechtvaardige wijze zijn mogelijkheid tot (be)handelen, ${ }^{19} \mathrm{a}$ en b Veeleer zall door het formuleren van criteria het bij te memen beslissingen hanteren van oneigenlijke en onzuivere argumenten kunnen worden tegengegaan, zodat rechtvaardige beslissingen kunnen worden genomen.

Met name ook de sociale en psychische factoren vragen in dit verband bijzondere aandacht. Deze liggen waak op het terrein van het functioneren van de mens in de maatschappij. Omstandigheden als stress, werkloosheid, onzekerheid over toekomstig bestaan, culturele veranderingen in leefpatroon e.d. gaan gepaard met een toename van vraag naar psychosociale en psychiatrische hulp. Deze problemen kunnen niet worden opgelost met uitsluitend medische maatregelen en evenmin door alleen psychiatrische en psychotherapeutische voorzieningen.

Voorts is het door de reeds genoemde toename van techniek en kennis weliswar mogelijk geworden lewens te verlengen, maar dit kan tevens inhouden dat niet alle problemen opgelost kunnen worden, zodat men soms levenslang is aangewezen op het institutionele zorgsysteem. Dit geldt voor geestelijk of lichamelijk gehandicapten, verpleeghuispatiënten, alsook voor sommige psychiatrische patiënten.

In dergelijke situaties bevindt de arts zich niet meer in de enkele arts-patiënt relatie, maar moet hij, evenals de patiënt, rekening houden met het instituutssysteem, dat wordt beheerst door eigen regels. Speciale andacht is nodig voor de rechtspositie van de patiënt, geplaatst in een door de institutionalisering extra afhankelijke positie, waarbij inbreuk op essentiële grondrechten dreigt. De jurist heeft hierbij een speciale beschermende rol te vervullen zowel ten aanzien van de arts, door hem te behoeden voor te gemakkelijke beslissingen, alsook ter bescherming van de patiënt, die recht heeft op eigen wilsbeschikking, op eigen oordeel omtrent leven en dood. In de geestelijke gezondheidszorg doet zich de ongelijkheid in de positie van de patiënt ten opzichte van het behandelingssysteem soms nog sterker dan in de somatische gezondheidszorg woor. Van de factoren die de evenwichtssituatie patient-behandelaar (c.q. behandelingssysteem) in de geestelijke gezondheidszorg negatief kunnen beïnwloeden, kunnen onder andere genoemd worden: geestelijke afhankelijkheid van de patiënt, het altijd sluimerend aanwezige element wan dwang, manipulatie ten gevolge van misbruik van machtspositie, de soms destructieve processen in therapeutische groepen.

Het is het doel van de geestelijke gezondheidszorg zo snel mogelijk de patiënt in een 
situate be brengen dat hil weer over zin eigen wil kan beshikken, dat hy weer ower zich zelf kan beslisser. Afweging wan middel en doel, in de somatische zorg een wel geaccepterd, how wel niet steeds toegepast beginsel, in in de geestelike gezondheidszorg een niet minder noodzakeligk uitgangspunt. 2 Rechtsegels ter bescherming van de patient in een door zijn geestesgesteldheid bijzonder kwetsbare positie, laten al te lang op zich wachten. Zo geld bijvoorbeld de Krankzinnigenwet van 1884 nog seeds. Aan het formuleren van woorwarden waraan gedragswetenschappelijke ex perimenten zouden dienen te woldoen, word nog niet gewerkt. Wettelijk geregelide wataborger woor beroepen in de geestelike gezondheidszorg met het oog op de kwaliteit van de hulpwerlening worden evenzeer nog steeds gemist, evenals een wettelijk geregeld tuchtrecht voor deze specifieke sector. Wildgroei in het bos der therapieen kan hierdoor vrijwel onbelemmerd zijn gang gaan.

Rechten die in de gezondheidszorg algemeen aanvard zijn, gelden ook in de geestelike gezondheidszorg en kunnen aan hen die in een psychiatrisch instituut zijn opgenomen, ongeacht of institutionalisering thet gevolg is van en rechterlijke uitspraak of niet, niet worden ontzegd.

\section{De medische en juridische meesters}

Na deze uiwweiding over de bevorderingsstazt, de te maken keuzes en de positie van patiënten keer ik terug naar het thema van de medische en juridische meesters, die men aan hun beperkingen kent.

De medische meesters maken het, zoals ik reeds opmerkte, mogelijk in te grijpen in de meris en diens nageslacht, waarop de juridische meesters moeten inspelen doon onder andere het uitwerken van bestaande regels en door het ontwikkelen van nieu* we juridische concepten.

Ik zal ter illustratie enkele voorbeelden noemen vam ontwikkelingen in de gezondheidszorg die consequenties hebben voor het gezondheidsniveau van toekomstige generaties.

Huidige mogelijkheden op het gebied van prenatale diagnostiek en therapie en de toepassing van recombinant-DNA techniek zijn van onmiskenbare waarde. Fundamented genetisch onderzoek heeft tot grote kennistoename geleid.

Kunstmatige bewruchtingstechnicken behoren tot de reảle mogelijkheden. Reeds nu ontlokken deze ontwikkelingen discussies van met name thische en juridische aard. Zo doek het gebruik van buitenbaarmoederlijk bewruchte embryo's vragen rijzen ten aanzien wan onderwerpen als wie is de ouder, aan wie behoort de bevruchte cel, wie is a nsprakelijk bij niet uitgekomen verwachtingen? ${ }^{21}$ an Ook het gebruik van ingevroren embryo"s voor voortplantings- en onderzoeksdaeleinden heeft tot bezorgdtheid anleiding gegeven. ${ }^{22}$ De wrag naar het toelatabare in relatie tot het te 
bereiken doel (the experiment should be such as to yield ruiful resullw for the good of society ....; Neurenberg code 1947) stat hierbij centraal."

Te verwachten valt dat het proces van nieuwe ontwikkelingen zich wal voor zerten en dat ook de praktische toepassingsmogelikheden zullen toenemen.

Uitbreiding wan mogelijkheden van prenatale diagnostiek, vergroting van de zekarheidsgraad buj het vastgtellen van geslachtsgebonden arfelike stofwisselingszieliten bij de vrucht, woortplantingsalternatieven, gebruik wan embryo's - gekweekt in la boratoria - woor levering van organen en weefsels, komen alls nieuwe ontwikkelingen in zicht.

Tegelijkertijd echter lijken mogelijkheden als genetische screening op positicye eigenschappen bij aanstellingskeuringen, selectie van mageslach op (vermeend positieve) eigenschappen (sex, ras, etnisch verbonden patronen), toepassing van gen-verandering bij mensen gericht op het nageslacht, in het vizier te komer. Parallel aan deze potentiele ontwikkelingen ontstaat de (theoretische) mogelijkheid wan overheidsingrijpen, op titel wan verantwoordelijkheid van de overheid voor ean gezond nageslacht.* Men denke bijvoorbeeld aan het aanleggen wan een genetisch registratiesysteem van de bevolking en het daaraan onder andere verbonden binnendringen in de persoonlijke levenssfeer, aan het stellen van regels ten aanzien van procreatie bij te verwachten overdracht van erfelijke afwijkingen e.d.

Fletcher ${ }^{23}$ gat zelfs zover te suggereren dat wij het tot onze plicht ten opzichte van de ongeborene zouden dienen te rekenen, gelet op onze genetische kennis, exn minimum standaard voom kwaliteit wan gezondheid en leven te stellen. * De mogelijkheid van het stellen van wettelijke regels ten alanzien van procreatie will hij zelfs in bepaalde omstandigheden nief uitsituten, zich daarbij onder andere beroepend op cnkele Anerikanse rechterlijke witspraten, waran het recht het leven met ex gezonde geest en een gezond lichaam te beginnen wordt erkend en het tocht op procreatie niet als een grondrecht wordt gezien.*** In dit verband wordt door Flotcher tevens ver" wezen naar de drie gronden, waarop sociale controle en regelgeving ten aanzicn van genetisch onderzoek en erfelijkheidsadvisering gebaseerd zouden kunnen zijn, zoals deze zijn geformuleerd door Welz en Thigpen in 1973, te weten, bescherming van wolksgezondheid en welzijn, bevondering van juiste verdeling van economische mid-

* Onder andene de Britse Medical Research Council heef richtijnen opgestad me betre

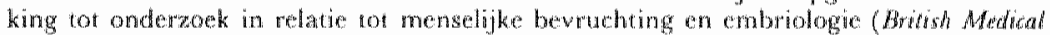
Jow wal, Vol. 235, 20 nowember 1982). Ook de "World Association of Children"s friend"s' heeft een verkaring opgeseld met betrekking tor medische experimenten op menselijke

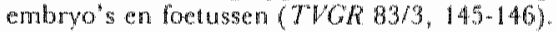

* Het voorkomen wan de noodzaak van instandhouding van kostbare zongwowateningen kan hierbij eveneens een argumeni zijn.

* * Fletcher maakt hierbij een vergelijking hel bepaalde vormen van wetgeving ingake huwe-

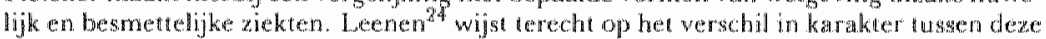
vormen van regelgeving en die indake het recht op procreatie.

* * * In Amerika zija reds rechtszaken bekend, warbij artsen en ouder(s) civielrecholijk worden aangesproken voor de geboorte van gehandicapte kinderen (zgn. "wongrobl-birthrand

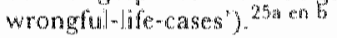


delen, vermindering van menselijk lijden. In nawolging van Leenen ${ }^{2 *}$ bepleit ik echter de grootste terughoudendheid van de kant van de overheid bij het maken van inbreuken op het zellbeschikkingsrecht van de mens.

Tot op heden wordt wrij algemeen onderschreven dat het treffen wan vrijwillige preventieve maatregelen de geëigende vorm is het overdragen van genetische ziekten en afwijkingen the beperken. "Toch ligt ook hierbij teen sluimerende mogelijkheid woor indirecte drang op anstalande ouders." Wij moten ons er van bewust zijn, dat anderen medische wetenschap en kennis zouden kunnen hanteren als machtsinstrument of zelfs als middel voor politieke manipulatie. Ook dienen wij ons te realiseren, dat negatieve consequenties voor het nageslacht kunnen voortvloeien uit (hedendaagse) toepassing van medische wetenschap. ${ }^{27}$ Bezinning van juristen, samen met artsen, op deze uit de voortgang wan de medische wetenschap en techniek voortwloei. ende problemen en op de ewentuele noodzaak tot ontwikkeling van een juridisch in= strumentarium in dit verband is een eerste wereiste. ${ }^{28}$ Daarbij moeten de positieve en negatieve aspecten tegenover elkaar worden afgewogen en dienen de nodige rechtswaarborgen te worden gecreêerd, met name ook om het zelfbeschikkingsrecht van de mens nitet aan te tasten.

De opperste rechter van hel hoog gerechtshof van de Verenigde Staten (Warren Burger') heeft gezegd ${ }^{29}$ : 'De eerste functie van het recht is het beschermen van grondwaarden van de mens, soms zelfs ten nadele van de wetenschappelijke vooruitgang.' Maar ook moet anderzijds het recht in positieve zin bijdragen door wetenschappelijke ontwikkelingen, die ten goede komen aan mens en samenleving, te reguleren.

De geneeskunde stelt vast wat medisch-technisch mogelijk is; de geneeskunde geeft geen antwoord op vragen als of wat medisch mogelijk is ook technisch en juridisch juist is; of en zo ja wanneer toepassing van medisch kunnen geoorloofd is. Voor beantwoording van dergelijke vragen staat onder andere het reche ten dienste. ${ }^{3}$ De jurist zal daarbij niet zonder de arts kunnen, de arts niet zonder jurist.

\section{Samenspraak}

Voorwaarde om dit te kunnen werwezenlijken is een regelmatig contact tussen artsen con juristen " * op verschillende niveaus (lokaal, regionaal en landelijk) en in verschillende kaders (zowel praktijkgericht als bij de wetenschapsbeoefening).

* De Maryland Commissie (Verenigde Staten) inzake erfellike afwijkirgen ${ }^{26}$ heeft onder an.dere bepaald, dat het weliswatar anvaardbat is regels te stellen ten aanzien van opspow ring en behestsing van erfelik owerdragbare atwijkingen, matr deze dienen te voldoen atn bepatde stringente voorwarden, waaronder de aanwezigheid van woorlichtings. en begeleidingswoorzieningen, die niet bindend mogen zijn en evenmin beperkingen mogen opleggen ten aamzien van het krijgen van kinderen.

- Drang kan uitgan wan hen die betrokken zijn bij de erfelijklectdsadwisering. Ook is het wiet ondenkbanar dat indien aanstande ouders beshiten het risico van een gehandicapt kind op zich te nemen, besloten word tot hel vragen van bijwoorbeeld een hoge eigen bijdrage ten behoeve van de verzorging van de gehandicapt geborenen.

* * Gerien de aragebrache beperking tot ants-jurest zijn ethici, wetke hier evenzer bij te berekken wijn, mick afzonderlik in de ondertartige beschouwing berokken. 
Ook is contact nodig tussen de regionale inspecties woor de (geestelijke) gezondheidszorg en gezondheidsjuristen, alsook op landelijk niveau nussen het Staatstoesicht voor de Volksgezondheid en gezondheidsjuristen. In het kader van de Vereniging voor Gezondheidsrecht is overigens reeds cen verbinding tussen de medische en juridische professic tot stand gekomen. Dit is ook het geval in de beraadsgroep gezond* heids-ethiek van de Gezondheidsraad, waar ook ethici zitring in hebben. Overwogen zou kunnen worden de positie van deze beraadsgropp verder te versterken en te structureren. Vragen, die voortwloeien uit de steeds verdergaande en daardoor steeds dieper in het menszijn ingrijpende medische wetenschap en de toepassing daarvan, alsmede vragen met betrekking tot de grenzen van de gezondheidszorg dienen tot de permanente aandachtsvelden van de Gezondheidsraad te behoren. Een adwiserende en initiërende taakstelling van de beraadsgroep zou het werk van de (commissies van de) Gezondheidsraad positief kunnen beïnloeden. Afweging tus" sen de nieuwe ontwikkelingen in de medische wetenschap en de toepassing daarvan in de gezondheidszorg enerzijds en de juridische aspecten daarwan, inclusief de consequenties voor toekomstige generaties, anderzijds, kan niet te vroeg plaatsvinden. Deze thematiek leent zich bij uitstek voor bestudering door de Grezondheidsraad. In dit verband acht ik het evenzeer gewenst om in de in het begin van dit jaar door de Staatssecretaris van Volksgezondheid ingestelde commissie met als opdracht het ontwikkelen van toekomstscenario's voor de gezondheidszorg"1 een jurist op te nemen. Juridische implicaties van voor de gezondheidszorg uitermate belangrijke beslissingen op het terrein van de grenzen van de zorg in relatie tot toekomstige ontwikkelingen, veranderingen en vernieuwingen dienen immers bij voorkeur niet achterar, maar tegelijkertijd onder ogen te worden gezien.

\section{Universitaire gezondheidsrechtelijke woorzieningen}

Ik ben mij er van bewust vele aspecten van het gezondheidsrecht en wan de relatie van dat recht tot de geneeskunde buiten beschouwing te hebben gelaten.

Ik ben voorts niet ingegaan op de noodzakelijke samenwerking tussen de juridische en andere disciplines dan de medische. Mijn stelling, dat het noodzakelijk is dat arts en jurist begrip voor elkaar hebben en met elkaar samenwerken ter bereiking van het gerneenschappelijk doel, geldr ook voor andere disciplines werkzaam in of betrokken bij de gezondheidszorg. Ik denk hierbij niet alleen aan paramedici, verpleegkundigen e.d., maar ook aan economen, sociologen, ethici, psychologen en anderen. Ik heb met rame aandacht gevraagd voor de relatie tussen de medische en juridische wetenschap ondat juridische problemen in de gezondheidszorg meer en meer zullen ontstaan door steeds verdergaand medisch wetenschappelijk onderzoek en de maalschappelijke toepassing daarvan.

Het behoud van de evenwichtssituatie tussen de twee grondrechten waarop onze gem zondheidszorg stoelt (het zelfbeschikkingsrecht wan de mens en het recht op gezond- 
heidszorg) in een periode warin zich de ontwikkelingen voordoen van de overgang van de 'verzorgingsstaat" naar de 'bevorderingsstatat' enerzijds en de voortgang van. grensverleggende medische kennis en kunde anderzijds vraagt een extra inspanning van het duo arts-jurist. Daartoe is onontbeerlijk de verdere uitbouw, onderbouwing en verdieping van universitair wetenschappelijk onderzoek en onderwijs onder andere aan medische studenten op het terrein van het gezondheidsrecht, waarbij an alle relevante factoren aandacht kan worden besteed. 52 Voorkornen moet daarom worden dat de ontwikkeling van het zich nog in het ontluikingsstadium bevindende universitaire gezondheidsrechtelijke potentieel uit hoofde van op korte termijnvisie gebaseerde bezuinigingsmaatregelen wordt geremd. De gezondheidsrechtelijke loot, welke sinds 1970 vanuit Amsterdam aan de universitaire stam tot groei is gebracht mout tot volle bloei kunnen komen, zowel landelijk gezien, als hier aan de Rijksuniversiteit te Maastricht.

Het ontwikkelen wan nieuwe concepten en methodieken, het voorkomen van een achaterstand in ontwikkeling, ook internationaal gezien, garanties dat het wolledige gezondheidsrechtelijke terrein kan worden bestreken en verzekering van continuïteit zijn daarbij van groot belang. Wil voorts worden voorkomen, dat aan de toenemende wraag naar onderwijs en onderzoek vanuit medische en juridische kringen niet meer kan worden voldaan en dat het groeiende beroep op gezondheidsrechtelijke deskundigheid vanuit internationale kaders onbeantwoord blijft, dan zal de overheid in het kader van de prioritaire rangschikking van universitaire voorzieningen uit hoofde wan kwaliteit en maatschappelijke relevantie het gezondheidsrecht op het prioritaire deel van de universitaire voorzieningenlijst dienen te platsen. ${ }^{33}$

Wat betreft de universiteit hier ter stede: De Algemene Faculteit heeft voor het gezondheidsrecht reeds een plaats ingeruimd in het curriculum. De Medische Faculteit, die het initiatief heefl genomen tot het creëren van een leerstoel gezondheidsrecht, is minder zover. Mede in verband met de specifieke oriëntatie van de medische opleiding alhier zal ook deze Faculteit ruime aandacht aan gezondheidsrechtelijke problemen en vraagstukken dienen te geven, als essentieel onderdeel van de opleiding. Ook voor onderzoek dienen de nodige mogelijkheden te worden geboden. Gezien het feit dat het gezondheidsrecht als horizontale discipline en als juridisch en juridisch-matschappelijk thema zich beweegt over het gehele terrein van het recht, zou het de Juridische Faculteit evenmin niet misstaan het gezondheidsrecht miet alleen fysieke ruimte, maar ook onderwijs en onderzocksgerichte mogelijkheden te geven. ${ }^{3 *}$

\section{Slotbeschouwing}

Tot slot rest mij een woord van dank uit te spreken aan Hare Majesteit de Koningin, die tot mijn benoeming aan dexe universiteit heeft besloten en aan allen aan deze universiteit die aan mijn benoeming hebben bijgedragen. I $\mathrm{k}$ zal rnij voor de realise- 
ring en ontplooing van het gezondheidsrecht aan deze universiteit inzetten en ik vertrouw op medewerking wan allen aan deze universiteit, studenten, wetenschappelijke medewerkers, collegae hoogleraren, te kunnen rekenen, zodat wij met onze capaciteitsgroep kunnen beantwoorden aan het beoogde doel. 


\section{Literaturaverwijzingen}

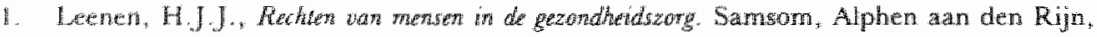
$1978,0.24-28$.

2. Lewen, H.J.J. De grenzen van de gezondheidszorg. $T$. Sor. Gezhz. 1983/11, p. $370-373$.

3. Korbeck, L.H.Th.S. Aard en doel wan het genesskndig handelen. In: Recent medichethisch dorken I. Statleu, Leiden, 1968, p. 37.

4. Zie noot $3 ;$ p. 25.

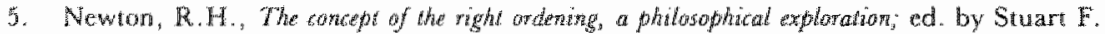
Spicker e. a Phorophy and medrine, wol. 9. D. Reidel publishing Company, Dordrecht (Holland) Boston (U. S.A.); London (England), 1981, p. 260-262.

6. Codefroi, L. S., Het Zuheryondswezen in Nederland. Martinus Nighof," s-Grawenhage, 1963 , p. $4 \%$.

7. Leenen, H.J.J. Struchur en funcioneren wan de gezortheidszorg. Samsom. Alphen aan den Rijn, 1981, th figt. VII.

8. Mijn, W, v.d., Beroepenwetgeving in de gezondlieidszorg. Medisch redh 6 . Kluwer, Deventer, $1982, p=20-23$.

9. Roscam Abbing, H.D.C., Rechten van patienten. Tid. Sor. Gehz. 1983/2, p. 41.

10. Roscam Abbing. H.D.C, Zolbeschikkingsrecht en rechi op integriteit van het menselijk

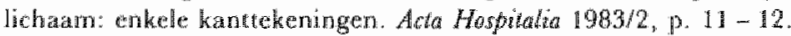

11. Werkgroep heregulering Rijksuniversiteit Leiden, Een geregeld verloop. Leiden, maart $1983, \mathrm{p} .21-22$

12. liskelens, A. W., Agere Votentem. Ürechi, 1983 , p. 13.

13. Hirsch Ballin, E.M.H. "De mens in de socialle rechisstat. In: Ouerheidsbemoeiemis. Kluwer, Deventer, 1982 , p. $21-33$

14. Beauchamp. T.L. en J.F. Childress, Princibles of biomedical eifnics. Oxford Univiersity Press. New York, Oxford, 1979, p. 189-192.

15. TVGR $82 / 3$, p. $111-117$

16. Van der Meer, J., Tachoig internisten per jaar voor de jaren tachtig. Ned. T. woor Gern. 12 Jebruari 1983, nr. 7 , p. 304.

17. Zie noot $2:$ p. 372 .

18. Es, J.C. wan, Grondslagen discussie. $M$. C. nr. 14, 18 april 1983, p. 391.

19a. Zie noot 14, p. 136 .

19b. Brock, D.W., Legal rights and moral responsibilities. In: The law - mudaine relation (zice noot 5), p. 281 .

20. Leenen, $\mathbb{H}_{\mathrm{J}} \mathrm{J}, \mathrm{J}$, Gezondheidsrech en rech. Samsom, Alphen aan den Rijn, 1981, p. 150 .

21 a. Holtzman, N.A. Public participation an genetic policy making. In: Genthis and the tawe II, ed, by Aubrey Milunski e. Bit. Plenum Press, New York, London, 1980, p. $247-255$.

21b. Dixor, B., Reageerbuis-baby expermenten. Para Medica, december 1982, p. 24-25,

22. Kuitent, H.M., Experimenten met embryo's, M.C. nr. 15, 15 april 1983, p. 433-435,

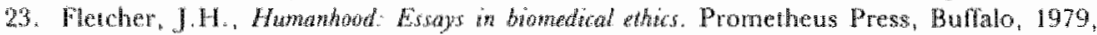
a.a. p. $113,12.122-128$.

24. Zie noot 1, p. 68 en 72 .

$25 a .2$. noor 23, p. 125.

25b. Holder, A.R., Is existence ever an injury? The wrongful life cases. In: The hat we medine relatrop (zie noot 5), p. 225-239. Willians, P.C., Wrongful life: a repiy wo Angela Holder; id. p. $240-251$.

26. ZR Bue noot 21 a 


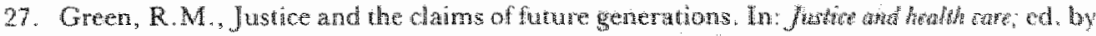

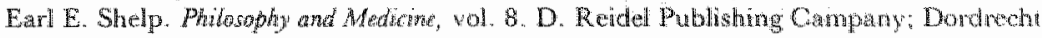
(Holland), Eoston (U S.A.), London (Engand): 1981, p. 201.

28. Zie noot 10.

29. Cenetics and the law If (zie noot 21a), Preface, p. IX.

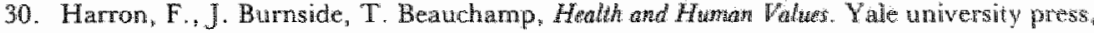
New Haven, London, 1983, p. 68-69.

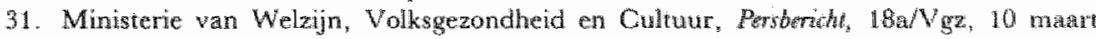
1983.

32. Leenen, H.J.J., Taak van het gezondheidsreche in de komende periode. TVOR, 19814, p. $156-161$.

33. Leenen, H.J.J., De behofte an universitaire voorzieningen voor gezondheidsreche. TVGR $1979 / 3$, p. $\mathbb{1 1 4 - 1 1 6 .}$

34. Verslag themadag over de juridische opleiting. $N / B$, 9 april 1983 ; p. $478-480$.

\section{Overige literatuur}

1. Biomedicat ethics and the law ed. by James M. Humber and Robert I. Almedes. Plenum Press, New York and London, 1976.

2. Galjaard, H., Erfelijkheidswoorlichting. Een verontachtzaand facet in de gevondheids. zorg. MGV 9/76, p. $443-455$.

3. Galjaard, H., Erfelijkheidsonderzoelk, wat doen we erroee. Para Media, december 1982, p. $22-23$.

4. Goudsmit, C.J., Volksgezondheid en rechu Vermande, 1966.

5. Meads, $C . K$ and DJ. Meador, The minds of the physician and the lawyer: a compariSon. Alabama Law Rewiw, vol. 22, nt. 3, 1970, p. 493-513.

6. Meer, C. v.d., Arts en jurist: een samenspel van overeenkomsten, verschillen, onzekerheden. TVGR 1978/2, p. $42-50$.

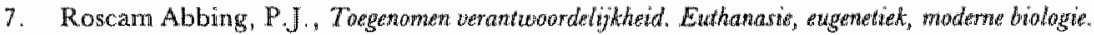
Callembach, Nijkerk, 1972.

8. Schenk, $W$, De jurist, zijn denkwijze en zijn houding tegenover de medicus. TVGR $1978 / 2$, p $51-56$.

9. Schuyt, C.J.M., Ongergeldheden. Naar theorie wan wetgeving in de verzorgingssiat. Samson, Alphen aan den Rijn, 1982. 